\title{
CLINICAL BLEEDING PATTERNS AND MANAGEMENT TECHNIQUES OF ABNORMAL UTERINE BLEEDING IN WESTERN KENYA.
}

\author{
Godfrey Shichenje Mutakha ${ }^{1}$, Emily Mwaliko ${ }^{1} \&$ Philip Kirwa ${ }^{1}$.
}

\section{Authors Affiliation:}

1. School of Medicine, Department of Reproductive Health - Moi University, Kenya.

@ Corresponding Author:

P.O. Box 4606-30100, Eldoret, Kenya.

E-mail: godfreymutakha@gmail.com,

Tel: +254721818754.

\section{Word Count:}

Abstract: 249 words

Main text: 2,261 words. 
medRxiv preprint doi: https://doi.org/10.1101/2020.06.01.20118968; this version posted June 2, 2020. The copyright holder for this preprint (which was not certified by peer review) is the author/funder, who has granted medRxiv a license to display the preprint in perpetuity.

\begin{abstract}
Background: Abnormal uterine bleeding (AUB) affects 30\% of reproductive age women globally. However, there are limited local studies evaluating the management of these women. The diagnostic guideline using structural and functional causes of AUB adopts the PALM-COEIN criteria, namely: Polyp; Adenomyosis; Leiomyoma; Malignancy and Hyperplasia; Coagulopathy; Ovulatory dysfunction; Endometrial; Iatrogenic; and Not yet classified. This study aimed to determine the clinical bleeding patterns and management of AUB among women in their reproductive age.

Methods: A cross-sectional study among 108 women with AUB aged 18-45 years was conducted at the gynaecology department of Moi Teaching and Referral Hospital in Western Kenya between April 2018 and April 2019. Their sociodemographic and clinical characteristics were collected using interviewer administered structured questionnaire and chart reviews. Adherence to diagnosis recommendations was assessed using PALM COEIN classification. Descriptive and inferential data analysis was conducted at $95 \%$ confidence interval.

Results: The median age was 30 (IQR: 22, 41) years with prolonged bleeding as the most predominant pattern at $41.7 \%$. Bleeding patterns were significantly associated with age $(\mathrm{p}=0.04)$. Only $16.7 \%$ were diagnosed as per the PALM-COEIN criteria with PALM and COEIN accounting for $60 \%$ and $40 \%$ respectively. Leiomyoma (44.5\%) was the common cause of AUB. Laboratory evaluation included: pregnancy tests, full Haemogram, hormonal profile and biopsy. Most (79.6\%) of the women had abdominopelvic ultrasound done. Medical management was provided for $78.7 \%$ of women.

Conclusion: Prolonged bleeding was the most common pattern with medical management preferred. There is need for in-hospital algorithms to ensure adherence to PALM-COEIN guidelines.
\end{abstract}

Keywords: PALM-COEIN, Abnormal Uterine Bleeding, AUB, women, reproductive age,

\title{
Western Kenya.
}


medRxiv preprint doi: https://doi.org/10.1101/2020.06.01.20118968; this version posted June 2, 2020. The copyright holder for this preprint

(which was not certified by peer review) is the author/funder, who has granted medRxiv a license to display the preprint in perpetuity.

All rights reserved. No reuse allowed without permission.

\section{Background}

Abnormal uterine bleeding (AUB) among women has a global prevalence of between 3 - 30\% [1] accounting for about one third of outpatient gynaecology visits. This condition affects the quality of life for women with socioeconomic and psychological consequences [1]. Its occurrence is dependent on temporal and quantitative regulation of reproductive hormones (hypothalamicpituitary-ovarian axis). The menstrual flow mediated by prostaglandins occurs following degeneration of the corpus luteum. Currently, the use of PALM-COEIN classification reduces the general inconsistency in the description of AUB in clinical and research settings. Although the PALM-COEIN classification guideline is the gold standard for AUB; it is not commonly used in many clinical settings leading to a lack of standardization in the diagnosis of women with AUB. There is limited documented studies on the bleeding patterns and management guidelines for women with AUB in Kenya.

Clinical patterns are determined by the heaviness, duration of flow, regularity and frequency. Management on the other hand includes the diagnostic techniques and therapeutic interventions offered to the affected women [2]. Diagnosis could be through laboratory, radiological and other imaging techniques [3]. Clinical management for women with AUB is either medical or surgical. Medical management is the first line therapeutic option once malignancy and pelvic pathology have been ruled out [4]. On the other hand, Surgical Management includes both minimal invasive techniques such as endometrial ablation for heavy menstrual bleeding [5] and invasive techniques such as hysterectomy and myomectomy. Hysterectomy is the definitive solution with high rates of patient satisfaction [6]. This study aimed to determine the clinical bleeding patterns and management of AUB among women in their reproductive age.

\section{Methodology}

This was a cross-sectional study among women presenting with abnormal uterine bleeding at Moi Teaching and Referral Hospital in Western Kenya from April 2018 to April 2019. The facility is the second largest tertiary hospital in Kenya catering for patients in Western and North Rift Valley regions of the country. A census was conducted among all the reproductive age (18-45 years) women seeking care for abnormal uterine bleeding. Patient's history and clinical information from medical records were collected. These included: the diagnostic tests done, final diagnosis made, and treatment given. Descriptive statistics were used to summarize categorical variables such as 
medRxiv preprint doi: https://doi.org/10.1101/2020.06.01.20118968; this version posted June 2, 2020. The copyright holder for this preprint (which was not certified by peer review) is the author/funder, who has granted medRxiv a license to display the preprint in perpetuity.

All rights reserved. No reuse allowed without permission.

level of education and marital status. Continuous variables such as age, duration of bleeding among others were summarized using mean and the corresponding standard deviation if the Gaussian assumptions hold. Otherwise they were summarized using median and the corresponding inter quartile range (IQR). Gaussian assumptions were assessed using histograms and the normal probability plots. Inferential statistics such as Pearson Chi-square were conducted to determine the level of statistical significance between predictor and outcome variables. The study's ethical approval was obtained from the Institutional Research and Ethics Committee of Moi University and Moi Teaching and Referral Hospital.

\section{Results}

The study enrolled a total of 108 women with AUB as per the flow chart on figure 1 . The mean age of the study participants was 31.46 years ( $\mathrm{SD} \pm 11.17$ ). Most $64.8 \%$ (70) of them had attained secondary level of education with $24.1 \%$ (26) having attended university/college level of education. Only $10.2 \%$ (11) were formally employed while more than half $(57.4 \%$; $=62)$ of all the participants living outside Eldoret.

\section{Abnormal Uterine Bleeding Patterns}

Prolonged bleeding was the most common (41.7\%) bleeding pattern followed by heavy (35.2\%), frequent (20.4\%), intermenstrual (18.5\%) and infrequent $(8.3 \%)$ bleeding as shown in Table 1.

\section{Management of women with $A U B$}

Management of women with AUB was categorized in terms of diagnosis and cost of management. Out of the 108 participants enrolled, only $16.7 \%$ (18) were diagnosed as per the PALM-COEIN criteria. However, there was no statistically significant difference (p-value $=0.364$ ) in abnormal uterine bleeding between the groups that were diagnosed as per the PALM-COEIN criteria versus those that were not (Table 2).

All the study participants had a pregnancy test done. This was followed by a complete blood count (CBC) test among nearly half $(45.3 \% ; n=49)$, coagulation profile $(25.9 \% ; n=28)$ and Thyroid Stimulating Hormone (TSH) at $12 \%(\mathrm{n}=13)$.

Additional hormonal profile laboratory tests were conducted based on menstrual cycle pattern (regular versus irregular). Overally, follicle stimulating hormone (FSH) was the most commonly (13\%) ordered among all the study participants with $13.2 \%$ of the women with regular menstrual cycles being subjected to it. This was followed by a TSH test that was commonly ordered for women with irregular (15\%) compared to those with regular $(10.3 \%)$ cycles. Prolactin hormone 
medRxiv preprint doi: https://doi.org/10.1101/2020.06.01.20118968; this version posted June 2, 2020. The copyright holder for this preprint (which was not certified by peer review) is the author/funder, who has granted medRxiv a license to display the preprint in perpetuity.

All rights reserved. No reuse allowed without permission.

test was the least frequently ordered. Estradiol and progesterone hormone tests were not ordered at all. There were no statistically significant relationships reported between menstrual cycle patterns (Table 3). Biopsy sampling was categorized by the participants age and whether it was done. Among women aged 35 years or less $(n=72)$, none of them had a biopsy specimen collected. On the other hand, those aged more than 35 years, only $8.3 \%(n=3)$ had biopsy sampling done. As per the PALM-COEIN classification, all women presenting with polyps, endometrial causes and non-classified abnormal uterine bleeding had a pelvic ultrasound done. Leiomyoma was the most commonly presenting cause of endometrial bleeding, of which more than two thirds $(68.8 \%$; $\mathrm{n}=33$ ) of the women presenting with it had a pelvic ultrasound ordered. Higher proportions of pelvic ultrasound requests were reported among those with adenomyosis (77.8\%; $\mathrm{n}=7)$, malignancy/hyperplasia $(84.6 \% ; n=11)$, ovulation dysfunction $(83.3 \% ; n=10)$ and iatrogenic $(91.7 \% ; n=11)$ causes of abnormal uterine bleeding (Figure 1). Even though $8.3 \%(n=9)$ of the participants presented with adenomyosis; none of them got an MRI scan done.

Majority of the women presenting with AUB were treated medically. Analgesics were given to nearly all $(92.6 \% ; n=100)$ the study participants while more than three quarters $(78.7 \% ; n=85)$ received antibiotics. Tranexamic acid (TXM) was prescribed to more than half $(61.1 \%$; $n=66)$ of the study participants, followed by haematinics $(39.8 \%$; $=43)$ while blood transfusion and combined oral contraceptives (COCs) were given to $6.5 \%(n=7)$ and $5.5 \%(n=6)$ respectively. No participant was given levonorgestrel intrauterine system (LGIUS), Progesterone only Pills (POP), androgens and gonadotropin releasing hormone agonists $(\mathrm{GnRH})$ as shown on figure 2 .

Surgical management was offered to $21.3 \%(\mathrm{n}=23)$ of all the study participants, majority $(69.6 \%$; $\mathrm{n}=16$ ) of whom got myomectomy done. This was followed by abdominal hysterectomy at $17.5 \%$ $(n=4)$. The less frequent procedures were dilatation and curettage (D\&C), polypectomy and oophorectomy at $4.3 \%(\mathrm{n}=1)$ each. No participant got uterine artery embolization (UAE), endometrial Ablation and vaginal or laparoscopic hysterectomy (Figure 3).

\section{Discussion}

The study was undertaken to determine the causes of abnormal uterine bleeding based on PALMCOEIN classification and the management options taken for the affected women.

This study reported that prolonged bleeding was the most common bleeding pattern seen among nearly half $(41.7 \%$; $n=45)$ of all the women enrolled into the study. This finding was higher than an Indian study [7] with one-third (33.6\%) of all the study participants presenting with prolonged 
medRxiv preprint doi: https://doi.org/10.1101/2020.06.01.20118968; this version posted June 2, 2020. The copyright holder for this preprint (which was not certified by peer review) is the author/funder, who has granted medRxiv a license to display the preprint in perpetuity.

All rights reserved. No reuse allowed without permission.

bleeding. The Indian study adopted a retrospective study design over a six-month period among 250 patients aged between 25 to 65 years. This variance in study design, period and target population could explain the variance in proportions of study participants. Prolonged bleeding was defined as more than eight (8) days of bleeding. It could have been easier to count more than 8 days than quantify other forms of AUB such as heavy bleeding.

Heavy Bleeding was the second most common AUB pattern among more than one-third (35.2\%; $\mathrm{n}=38$ ) of all enrolled study participants. This finding is matched a Brazilian study that reported a proportion of women with heavy bleeding at $35.3 \%$ [8]. Both studies adopted cross-sectional study designs among women aged 18-45 years and this could explain the similarity in proportions.

Frequent bleeding was the third most frequent AUB pattern among nearly one-fifth $(18 \% ; n=22)$ of all the study participants. This proportion is similar to the findings in another Indian study where $17 \%$ of all the women enrolled complained of frequent bleeding [9]. This similarity could be attributed to the fact that both studies targeted women in their reproductive years and were both conducted in teaching hospitals.

Less than one-fifth $(16.7 \%$; $=18)$ of all the study participants were diagnosed as per the PALMCOEIN criteria. Preoperative classification of AUB as per PALM-COEIN classification system was correctly done among 130 (65.0\%) of the 200 women in a study in a low resource setting [10]. However, the overall proportion of participants who met the PALM and COEIN criteria accounted for $60 \%(n=64)$ and $40 \%(n=44)$ respectively. This matched an Indian study [11] where 60.4\% and $39.6 \%$ were diagnosed as per the PALM and COEIN criteria respectively. This similarity could be attributed to the fact that both studies were done in a tertiary teaching hospital among non-pregnant women over a period of one year. In a retrospective analysis of women who underwent a planned abdominal hysterectomy for AUB, leiomyoma was most common cause at $44.2 \%$ [12]. This finding is comparable to the current study's finding of nearly half (44.4\%) of all study participants presenting with leiomyoma as the most common cause of abnormal uterine bleeding.

Malignancy and hyperplasia were the second most common abnormalities with a proportion of $12 \%(\mathrm{n}=13)$. There were equal proportions iatrogenic and ovulation dysfunction among the women sampled at $11.1 \%(n=12)$. This matched an Indian study [9] where $13.6 \%$ of the study participants presented with malignancy and hyperplasia.

The most frequent laboratory tests conducted among the enrolled women with abnormal uterine bleeding were pregnancy tests (100\%), complete blood counts $(45.3 \%)$ and coagulation profile 
medRxiv preprint doi: https://doi.org/10.1101/2020.06.01.20118968; this version posted June 2, 2020. The copyright holder for this preprint (which was not certified by peer review) is the author/funder, who has granted medRxiv a license to display the preprint in perpetuity.

All rights reserved. No reuse allowed without permission.

(25.9\%). Follicle stimulating hormone (13\%) and thyroid stimulating hormone (12\%). There were low proportions of and prolactin hormone (2.8\%) tests. However, no participant got laboratory requests for Estradiol, progesterone and luteinising hormone. Only 3 (2.7\%) participants had a biopsy sample taken. This was done only among women aged below 35 years.

Abdominopelvic ultrasound was done for the majority $(79.6 \% ; n=86)$ of the study participants to rule out structural causes of AUB. Those (20\%) who did not have the ultrasound scans done were due to lack of funds or clinicians not requesting. This finding compares to a Pakistani study [13] in which all the study participants had an abdominopelvic ultrasound done. However, the findings contrast those in the Netherlands where only $10 \%$ of the women presenting with AUB had an abdominopelvic ultrasound conducted [14].

Medical and Surgical management was offered to $78.7 \%(n=85)$ and $21.3 \%(n=23)$ respectively. Analgesics were prescribed to nearly all (92.6\%) of the study participants followed by antibiotics (78.7\%) and antifibrinolytics (61.1\%). This finding contrasted a Dutch study [14] where nearly two thirds $(62 \%)$ of the study participants did not receive any medication. Analgesics were prescribed among $5 \%$ of the study participants who presented with excessive bleeding. This could be due to the fact that majority of the women were initially seen by General Practitioners and only a few referred to gynecologists. A systematic review [15] by the Vanderbilt Evidenced based practice center of six studies on non-steroidal anti-inflammatory drugs (NSAIDS) among women with AUB; reported that NSAIDS reduced bleeding in the participants enrolled in all the six studies. The study further reported that tranexamic acid (TXA) was more effective in reducing bleeding than NSAIDS in three out of four studies reviewed.

Hematinics used at 43(39.8\%) while blood transfusion done in 7(6.5\%) although more than $56 \%$ needed them. Combined oral contraceptives were prescribed among 5.5\% of the study participants enrolled in this study. This was lower than the $35 \%$ of women who received hormonal treatment in the Netherlands [14]. A treatment algorithm for AUB [16] recommended that abnormal bleeding persists after three months, a higher dose of oral contraceptives can be used.

\section{Conclusions and Recommendations}

Prolonged bleeding was the most common bleeding pattern seen at MTRH followed by heavy bleeding. Less than one-third (16.7\%) of all women were correctly diagnosed as per the PALMCOEIN classification guidelines. Women with prolonged bleeding should be evaluated for abnormal uterine bleeding. More training and development of in-hospital algorithms should be 
medRxiv preprint doi: https://doi.org/10.1101/2020.06.01.20118968; this version posted June 2, 2020. The copyright holder for this preprint (which was not certified by peer review) is the author/funder, who has granted medRxiv a license to display the preprint in perpetuity.

All rights reserved. No reuse allowed without permission.

done to ensure adherence to PALM-COEIN guidelines in the diagnosis of abnormal uterine bleeding. Medical management should be opted for as the first line of management for women presenting with abnormal uterine bleeding.

\section{What is already known on this topic}

- Abnormal uterine bleeding affects women of reproductive age.

- The recommended diagnostic guideline is using the PALM-COEIN classification.

- There is limited documented studies on the bleeding patterns and management guidelines for women with AUB in Kenya.

- Management of AUB has been reported to be costly by studies done in other settings, further complicating patient management and outcomes.

\section{What this study adds}

- Prolonged and heavy bleeding are the most common abnormal uterine bleeding patterns in Western Kenya.

- This study shows that the PALM-COEIN diagnostic criteria is not commonly used in Western Kenya.

- The study further compares PALM-COEIN diagnostic criteria with the management offered for women with AUB in western Kenya.

\section{Acknowledgement:}

- Moi Teaching and Referral Hospital management and health records department alongside Moi University Department of Reproductive Health.

\section{Competing Interests:}

- The authors declare no financial conflict of interest or any other non-financial competing interests.

\section{Author Contribution:}

1. GSM, EM and PK: Substantial contributions to conception and design of the study.

2. GSM, EM and PK: Acquisition of data, analysis and interpretation of data designed and carried out data collection and participated in drafting the manuscript.

3. GSM, EM and PK drafting the article or revising it critically for important intellectual content.

4. GSM, EM and PK: Final approval of the version to be published intellectual content. They also gave the final approval of the version to be published and have agreed to be accountable for all aspects of this work. 
medRxiv preprint doi: https://doi.org/10.1101/2020.06.01.20118968; this version posted June 2, 2020. The copyright holder for this preprint (which was not certified by peer review) is the author/funder, who has granted medRxiv a license to display the preprint in perpetuity.

\section{REFERENCES}

1. Liu Z, Doan Q V., Blumenthal P, Dubois RW. A Systematic Review Evaluating HealthRelated Quality of Life, Work Impairment, and Health-Care Costs and Utilization in Abnormal Uterine Bleeding. Value Heal. 2007;10: 183-194. doi:10.1111/j.15244733.2007.00168.x

2. Kotdawala P, Kotdawala S, Nagar N. Evaluation of endometrium in peri-menopausal abnormal uterine bleeding. J Midlife Health. 2013 [cited 25 Jan 2017]. Available: http://www.jmidlifehealth.org/article.asp?issn=09767800; year $=2013 ;$ volume $=4 ;$ issue $=1 ;$ spage $=16 ;$ epage $=21 ;$ aulast $=$ Kotdawala

3. Abdullahi YM, Ajani MA, Iyapo O, Aramide KO, Okolo CA, Akang E. Morphological Pattern of Endometrial Biopsies in Southwestern Nigeria. Ann Ibadan Postgrad Med. 2016;14: 103-109. Available: http://www.ncbi.nlm.nih.gov/pubmed/28337096\%0Ahttp://www.pubmedcentral.nih.gov/a rticlerender.fcgi?artid=PMC5354619

4. Walraven G, Scherf C, West B, Ekpo G, Paine K, Coleman R, et al. The burden of reproductive-organ disease in rural women in The Gambia, West Africa. Lancet. 2001;357: 1161-1167. doi:10.1016/S0140-6736(00)04333-6

5. Harlow SD, Campbell OMR. Epidemiology of menstrual disorders in developing countries: a systematic review. BJOG An Int J Obstet Gynaecol. 2004;111: 6-16. doi:10.1111/j.14710528.2004.00012.x

6. Weber A. Risk factors for endometrial hyperplasia and cancer among women with abnormal bleeding. Obstet Gynecol. 1999;93: 594-598. doi:10.1016/S0029-7844(98)00469-4

7. Anuradha S, Premlata M, Nupur H, Alka B, Pradeepkumar S, Ramesh B. Spectrum of Endometrial Histopatholozgy in Women Presenting with Abnormal Uterine Bleeding. 2015 $\begin{array}{llll}\text { [cited } & 7 & \text { Oct } & \text { 2019]. Available: }\end{array}$ https://www.google.com/search?q=Spectrum+of+Endometrial+Histopathology+in+Wome $\mathrm{n}+$ Presenting+with+Abnormal+Uterine+Bleeding+Anuradha+Salvi1*\%2C+Premlata+Mit al2+\%2C+Nupur+Hooja3+\%2C+Alka+Batar4+\%2C+Pradeepkumar+Soni5+\%2C+Rame sh+Beniwal6+1+Senior+Resident $\% 2 \mathrm{C}+$ 
medRxiv preprint doi: https://doi.org/10.1101/2020.06.01.20118968; this version posted June 2, 2020. The copyright holder for this preprint (which was not certified by peer review) is the author/funder, who has granted medRxiv a license to display the preprint in perpetuity.

8. Santos IS, Minten GC, Valle NCJ, Tuerlinckx GC, Silva AB, Pereira GAR, et al. Menstrual bleeding patterns: A community-based cross-sectional study among women aged 18-45 years in Southern Brazil. BMC Womens Health. 2011;11: 26. doi:10.1186/1472-6874-1126

9. Mahapatra M, Mishra P. Clinicopathological evaluation of abnormal uterine bleeding. J Heal Res Rev. 2015;2: 45. doi:10.4103/2394-2010.160904

10. Shubham D, Kawthalkar AS. Critical evaluation of the PALM-COEIN classification system among women with abnormal uterine bleeding in low-resource settings. Int J Gynecol Obstet. 2018;141: 217-221. doi:10.1002/ijgo.12388

11. Betha K, Malavatu L, Talasani S. Distribution of causes of abnormal uterine bleeding using new FIGO classification system-PALM COEIN: a rural tertiary hospital based study. Int J Reprod Contraception, Obstet Gynecol. 2017;6: 3523. doi:10.18203/23201770.ijrcog20173476

12. Mohammed N, Prejisha D. A Study of Correlation of Etiological and Histopathological Findings in Females Undergoing Hysterectomy for Abnormal Uterine Bleeding - in Accordance with Palmcoein Classification. 2014.

13. Khan F, Jamaat S, Al-Jaroudi D. Saline infusion sonohysterography versus hysteroscopy for uterine cavity evaluation. Ann Saudi. 2011 [cited 2 Feb 2017]. Available: http://pubmedcentralcanada.ca/pmcc/articles/PMC3156516/

14. de Vries CJH, Wieringa-de Waard M, Vervoort CLAG, Ankum WM, Bindels PJE. Abnormal vaginal bleeding in women of reproductive age: A descriptive study of initial management in general practice. BMC Womens Health. 2008;8: 1-6. doi:10.1186/14726874-8-7

15. Hartmann K, Jerome R, Lindegren ML, Potter S, Shields T, Surawwicz T, et al. Primary Care Management of Abnormal Uterine Bleeding. 2013; 528.

16. Ely JW, Kennedy CM, Clark EC, Bowdler NC. Abnormal uterine bleeding: A management algorithm. J Am Board Fam Med. 2006;19: 590-602. doi:10.3122/jabfm.19.6.590

\section{APPENDICES}


Table 1: Abnormal Uterine Bleeding Patterns seen at MTRH

\begin{tabular}{|l|l|l|}
\hline Bleeding pattern & Frequency & Percentage \\
\hline Prolonged bleeding & 45 & 41.7 \\
\hline Heavy bleeding & 38 & 35.2 \\
\hline Frequent bleeding & 22 & 20.4 \\
\hline Intermenstrual bleeding & 20 & 18.5 \\
\hline Infrequent bleeding & 9 & 8.3 \\
\hline
\end{tabular}

Table 2: Diagnosis as per the PALM-COEIN Criteria

\begin{tabular}{|l|l|l|l|l|l|l|l|l|l|l|}
\hline Diagnosis & P & A & L & M & C & O & E & I & N & Totals \\
\hline Yes & 1 & 1 & 13 & 1 & 0 & 2 & 0 & 0 & 0 & $18(16.7 \%)$ \\
\hline No & 5 & 8 & 35 & 12 & 0 & 10 & 7 & 12 & 1 & $90(83.3 \%)$ \\
\hline Total & 6 & 9 & 48 & 13 & 0 & 12 & 7 & 12 & 1 & $108(100 \%)$ \\
\hline
\end{tabular}

(p-value $=0.364)$.

Table 3: Laboratory testing of Hormonal Profiles as per the menstrual cycles

\begin{tabular}{|l|l|l|l|l|l|l|}
\hline Cycle & TSH & Estradiol & Prolactin & Progesterone & FSH & LH \\
\hline Regular $(\mathrm{n}=68)$ & $7(10.3 \%)$ & 0 & $1(1.5 \%)$ & 0 & $9(13.2 \%)$ & 0 \\
\hline Irregular (n=40) & $6(15 \%)$ & 0 & $2(5 \%)$ & 0 & $5(12.5 \%)$ & 0 \\
\hline Total (N=108) & $13(12 \%)$ & 0 & $3(2.8 \%)$ & 0 & $14(13 \%)$ & 0 \\
\hline P-value & 0.468 & - & 0.281 & - & 0.913 & - \\
\hline
\end{tabular}

